\title{
PENERAPAN PEMANFAATAN TEKNOLOGI DITINJAU DARI TEORI KEPRIBADIAN MORAL
}

\author{
(Studi Deskriptif Nilai- Nilai Moral Aristoteles Pada Perilaku konsumen Dalam Penerapan \\ Pemanfaatan Teknologi di Jakarta)
}

Yohanes Probo Dwi

Program Studi Psikologi Universitas Bunda Mulia yprobo@bundamulia.ac.id

\begin{abstract}
Growth and technological development, and the advancement of human life, evolved very significantly. The existence of technology and human existence now, as if like two sides of a coin that can not be separated. Both are present and are complementary to one another. The mushrooming of the movement and growth of technology, consciously or unconsciously have brought their own impact on the shift in human behavior. Both the positive and negative sides. Understanding the concept of moral values according to Aristotle, was a call at the same time moral teachings for us, especially for the actors, as well as users of technology. So that we as individuals take advantage of the technology have an attitude of readiness, understanding and make him more human. The research, by promoting descriptive qualitative research methods, attempts to provide an overview of the concrete situation of the life of the perpetrators of technology users. Data obtained based on the facts in interviews and presented systematically. The orientation of the paper, that we realize in earnest to implement and apply the cultivation of religious values and ethics in our lives. Character building education at the same time for all users of the technology, needed proclaimed and scheduled as an educational curriculum, both formal and informal. A program of continuous work. With the main objective, enhance the dignity of human life, as well as more broadly as the promotion of human life to the nation.
\end{abstract}

Keywords: moral attitude, Consumer, Roles, Applications, Technologies

\begin{abstract}
ABSTRAK
Pertumbuhan dan perkembangan teknologi, serta kemajuan kehidupan manusia, berkembang sangat signifikan. Keberadaan teknologi dan eksistensi manusia kini, seolah- olah seperti dua sisi mata uang yang tidak dapat dipisahkan. Keduanya hadir dan saling melengkapi satu dengan yang lainnya. Menjamurnya pergerakan dan pertumbuhan teknologi, disadari atau tidak telah membawa dampak tersendiri pada pergeseran perilaku manusia tersebut. Baik dalam sisi positip maupun negatif. Konsep pemahaman nilainilai moral menurut Aristoteles, merupakan sebuah seruan sekaligus ajaran moral bagi kita, khususnya bagi pelaku, sekaligus pemakai teknologi. Agar kita sebagai insan yang memanfaatkan teknologi memiliki kesiapan sikap, pemahaman dan menjadikan dirinya semakin manusiawi.

Penelitian, dengan mengedepankan metode penelitian Kualitatif deskriftif, berupaya memberikan gambaran mengenai situasi konkrit kehidupan para pelaku pemakai teknologi. Data diperoleh berdasarkan fakta- fakta dalam wawancara dan disajikan secara sistematis. Orientasi akhir penelitian ini, bahwa kita sadar dengan sungguh- sungguh bisa mengimplementasikan dan mengaplikasikan penanaman nilai- nilai agama dan etika dalam kehidupan kita. Pendidikan sekaligus pembinaan karakter untuk seluruh pemakai teknologi, perlu dicanangkan dan diagendakan sebagai sebuah kurikulum pendidikan, baik formal maupun informal. Sebuah program kerja berkesinambungan. Dengan tujuan utamanya, meningkatkan harkat hidup manusia, serta lebih luas lagi sebagai upaya memajukan kehidupan manusia bagi bangsa dan negara.
\end{abstract}

Kata kunci: Sikap moral, Konsumen, Peran, Aplikasi, Teknologi

\section{PENDAHULUAN}

\subsection{Latar Belakang}

Teknologi dalam segala aspek dan sepak terjangnya. Secara sadar atau tidak. Dikenali atau tidak. Telah membawa perubahan dalam diri manusia. Baik itu dari pola pikir. Sikap dan kebiasaan.

Keberadaan teknologi kini, seakan tidak bisa dilepas- bebaskan dari kehidupan manusia. Keberadaannya seolah- olah tidak bisa digantikan dan dipisahkan satu dengan yang lainnya.

Dengan jujur kita mengakui. Dibalik kehadiran teknologi dengan segala dimensi dan aspeknya. Ada dampak atau hal yang ikut menyertainya. Ada sisi positif yang bisa kita ambil dari teknologi tersebut. 
Namun, ada pula,sisi negatifnya yang harus kita cermati secara seksama.

Dalam pelbagai sumber informasi yang didapatkan. Ditemukan, data dan fakta sebagai berikut. Pada, Kompas.com. edisi Senin, 26 Mei 2014. Dalam konfrensi tahunan persatuan guru dan dosen, ATL, yang berlangsung di Belfast, Kamis, 22 Mei 2014. Tenaga pendidik di Irlandia Utara menangkap sinyal kekhawatiran yang luar biasa pada diri peserta didiknya. Mereka khawatir dengan banyaknya waktu yang terbuang percuma oleh anak dalam memakai komputer dan peralatan digital lain, diluar lingkungan sekolah. Hal yang di dapat dari perubahan sikap tersebut, para pelajar memiliki perubahan tingkah laku. Dan perangai. Dampak lebih jauh yang dapat dirasakan, para peserta didik tidak bisa untuk berkonsentrasi dalam belajar. Lebih disayangkan lagi, mereka tidak bisa berinteraksi dengan sesama serta bermain.

Contoh lainnya. Senin, 28 April 2014. Terjadi tindak kriminal yang dilakukan oleh sejumlah anak- anak dibawah umur. Dalam kasus tersebut,. Anak- anak dimanfaatkan untuk dijadikan kurir dalam menyeludupkan handphone, ke negara tetangga.

Penyeludupan telepon genggam dari China ke Hongkong. Anak- anak sekolah dengan belbagai cara telah di kendalikan oleh mereka yang tidak bertanggung jawab.

Faktor dan sumber lain, yang membuat penulis tertarik untuk membuat paper ini, adalah, saat penulis bercakapcakap dengan beberapa nara sumber mengenai kesan dan sikapnya dalam memanfaatkan teknologi. Khususnya dengan handphone, salah satu hasil teknologi yang selalu ada dalam genggaman tiap manusia.

Ketika berbincang- bincang dengan beberapa karyawan di beberapa tempat kerja dan dari berbagai lokasi berbeda. Hal yang dapat mereka ceritakan, mengenai pengalaman selama ini mereka memanfaatkan teknologi. Beberapa nara sumber menceritakan serta mengisahkan, bahwa teknologi yang mereka manfaatkan selama ini, khususnya hand phone.

Nara sumber pertama, adalah pekerja pada bidang teknik. Ketika mengisahkan mengenai pengalamannnya dalam memanfaatkan teknologi. Ia menuturkan bahwa ia sangat tidak begitu senang bila bekerja diganggu oleh handphone. Ia merasa tidak focus, dan terganggu. Sebentar- sebentar harus melakukan pembicaraan.

Nara sumber berikutnya, adalah seorang tenaga pendidik. Penulis mencoba menanyakan kepada nara sumber, mengenai pengalamannya sebagai karyawan di tempat ia bekerja sekarang. Ia menuturkan bahwa, ia sangat terbantu dengan adanya teknologi. Dalam mengajar dikelas 1, 2 dan 3 Sekolah Menengah Atas, ia merasa tertolong ketika memberi penjelasan dengan memakai teknologi hand phone atau media teknologi pembelajaran lainnya. Ketika ada hal yang tidak diketahui, ia tinggal mencari di internet. Kemudian dalam waktu sekejap, dia bisa medapatkan apa yang dibutuhkannya.

Pada nara sumber ketiga. Ditempat yang berbeda pula, penulis mewawancarai seorang tanaga kerja pada suatu bank swasta. Dalam diskusi ringan tersebut, karyawan menuturkan bahwa, pengalaman yang ia alami, selama memakai teknologi, ia sangat dipermudah dengan teknologi, tapi dia hanya memanfaatkan sebatas kebutuhannya. Untuk hal lain yang bernuansa ke arah negatif dia menolaknya.

Dari beberapa uraian diatas, dengan pelbagai pengalaman dan cerita yang dituturkan oleh nara sumber. Jelas tergambar beberapa sikap dan penilaiannya mengenai teknologi. Ada dampak- dampak yang baik yang coba diambil dan dinilai. Namun, ada pula faedah yang tidak bermanfaat yang ditolak serta tepikannya.

\subsection{Tujuan Penelitian.}

Penelitian ini bertujuan untuk memberikan gambaran singkat, bagaimana sikap moral konsumen dalam peran dan aplikasinya terhadap teknologi dilingkungan tempat mereka melakukan aktivitas. Disamping itu pula, bagaimana nilai- nilai moral yang digagas oleh Aristoteles dapat semakin mewujudnyatakan kepribadian moral para konsumen teknologi di Jakarta.

\section{LANDASAN TEORI}


Pada tahap ini, penulis akan menguraikan mengenai landasan teori, yakni meliputi: sikap moral, tenaga pekerja, peran, aplikasi dan teknologi.

\subsection{Sikap Moral}

Dalam Kamus Besar Bahasa Indonesia. Sikap, diartikan sebagai a). adalah merupakan reaksi atau proses seseorang yang masih tertutup terhadap suatu stimulus atau obyek. Sikap tidak dapat dilihat langsung tetapi hanya dapat di tafsirkan terlebih dahulu dari perilaku yang tertutup. b). Sebagai suatu pola perilaku, tendensi atau kesiapan antisipatif, predisposisi untuk menyesuaikan diri dalam situasi sosial atau secara sederhana sikap adalah respon terhadap stimuli sosial yang telah terkondisikan.

Dalam buku yang ditulis oleh J. Sudarminta "Etika Umum". pengertian moral, secara etimologis sama dengan etika. Kata moral berakar dari kata latin moris, yakni adat kebiasaan. Sebagai istilah, kedua hal tersebut, kerap dibedakan. Itilah etika dipakai untuk menyebut ilmu dan prinsip dasar, penilaian- penilaian mengenai baikburuknya perilaku manusia sebagai manusia. Sedangkan istilah moral untuk menguraikan mengenai aturan dan norma yang lebih konkret bagi penilaian tentang baik- buruknya perilaku manusia.

\subsection{Tenaga Pekerja}

Pengertian tenaga pekerja, dalam konteks ini, dapat diuraikan sebagai: a). Orang yang bekerja atau mengerjakan sesuatu: pekerja, pegawai dan sebagainya. b). Orang yang mampu melakukan pekerjaan, baik di dalam maupun di luar hubungan kerja (artikata.com).

\subsection{Dalam Peran}

Pengertian dalam peran, dipahami sebagai; keadaaan atau situasi; 1).peran: pemain sandiwara 2). Perangkat Tingkah yang diharapkan dimiliki oleh orangorang yang berkedudukan dalam masyarakat.

\subsection{Aplikasi}

Pemahaman Aplikasi dalam makna sesungguhnya bisa ditemukan, mengacu pada pengertian: pelaksanaan; penerapan. Penggunaan secara Konteks ini mengacu pada pemahaman bagaimana sesuatu hal itu dilakukan. Di kerjakan dalam konteks bersangkutan.

\subsection{Teknologi}

Teknologi, bisa dipahami sebagai:

1. Keseluruhan sarana untuk menyediakan barang- barang yang diperlukan bagi kelangsungan dan kenyamanan hidup manusia secara umum.

2. Entitas, benda maupun tidak benda yang diciptakan secara terpadu melalui perbuatan dan pemikiran untuk mencapai suatu nilai.

\section{METODE PENELITIAN}

Penelitian ini menggunakan metode penelitian kualitatif dengan sudut pandang konstruktif. Dalam pemahaman penelitian kualitatif, realitas yang ada. Fenomena yang tampak, dikonstruksi secara sosial, yakni berdasarkan konvensional.

Hasil konstruksi itu dipengaruhi sifat hubungan antara peneliti dengan yang diteliti, serta kendala-kendala situasional di antara keduanya. Penelitian kualitatif merupakan penelitian yang bersifat penafsiran dan melibatkan banyak metode, dalam menelaah masalah penelitiannya. Penggunaan berbagai metode ini -sering disebut triangulasi- dimaksudkan agar peneliti memperoleh pemahaman yang komprehensif.

Terdapat beberapa pandangan mendasar yang menjadi patokan penting dalam penelitian kualitatif: 1). Realitas sosial adalah sesuatu yang subyektif dan diinterpretasikan, bukan sesuatu yang lepas di luar individu-individu; 2). Manusia tidak secara sederhana disimpulkan mengikuti hukum-hukum alam di luar diri, melainkan menciptakan rangkaian makna dalam menjalani hidupnya; 3). Ilmu didasarakan pada pengetahuan sehari-hari, bersifat induktif, ideografis dan tidak bebas nilai; 4). Penelitian bertujuan untuk memahami kehidupan sosial. 5). Dunia fenomena adalah dunia yang kita alami dengan panca indera, artinya realitas yang ada disekitar, 
dicecap dan ditangkap oleh kinerja panca indera.

\subsection{Studi Kasus}

Studi kasus adalah fenomena khusus yang hadir dalam konteks yang terkondisikan. Dunia fenomena adalah dunia yang kita alami dengan seluruh aktivitas panca indera kita, dan terbentang luas bagi kemungkinan adanya ketertarikan untuk lebih memaknai serta mencari hasil dari apa yang menggangu secara rasional. Ilmu memerlukan penelitian dan realitas menjadi dunia fenomena. Meski batas-batas antara fenomena dan konteks tidak sepenuhnya jelas. Namun, Kasus itu dapat berupa individu, peran, kelompok kecil, organisasi, komunitas, atau bahkan suatu bangsa. Kasus dapat pula berupa keputusan, kebijakan, proses, atau suatu peristiwa khusus tertentu. Pendekatan studi kasus membuat peneliti dapat memperoleh pemahaman utuh dan terintegrasi mengenai konstruksi berbagai fakta dan memakni lebih atas dimensi dari kasus tersebut.

Dalam pendekatan atau tipe penelitian studi kasus, metode pengumpulan data dilakukan dari berbagai sumber dengan beragam cara, bisa berupa observasi, wawancara, maupun studi dokumen atau karya atau produk tertentu yang terkait dengan kasus.

\subsection{Subyek Penelitian}

Jumlah Subyek yang diambil dalam penelitian ini, sebanyak 3 orang. Subyek penelitian ini ini, terdiri dari karyawan PT. E. Seorang karyawan sudah bekerja selama kurang lebih 5 tahun. Berikutnya, seorang tenaga pengajar di Sekolah SMA "P". Tenaga pengajar dengan masa ajar, sekitar 8 tahun. Terakhir, Karyawan di Bank U. Seorang karyawati dengan jabatan legal manager. Dia sudah bekerja selama kurang lebih 6 tahun.

Pemilihan jenis pekerjaan ini, didasarkan atas lokasi yang beraneka ragam. Tingkat interaksi yang dilakukan oleh responden dalam mengaplikasikan nilai- nilai moralnya, serta bagaimana relasi yang dibangun dalam mengaplikasikan dalam tindakan keseharian mereka dalam bekerja. Sekolahan ini dipilih karena berada dalam lokasi yang berbeda. Sekolah SMA P berada didaerah Bekasi- Jawa barat. Dengan jumlah siswa yang lumayan banyak. Media pembelajaran dengan menggunakan teknologi yang modern. Laboratorium yang menunjang dengan perangkat- perangkat yang memadai di Sekolah.

Sementara Bank U, berlokasi di Jakarta Pusat. Bank ini juga memiliki sejumlah karyawan yang cukup banyak serta pemakaian teknologi yang modern, signifikan untuk menunjang kinerja para karyawan.

PT. E adalah sebuah perusahaan yang menyediakan materi konstruksi baja untuk beberapa keperluan, seperti pembuatan plat- plat jalanan, papan reklame dan sebagainya. teknologi yang dipakai sebagai alat pembuat dan penunjang kinerja mereka juga terdiri atas seperangkat teknologi modern.teknologi yang dapat menunjang pelaksanaan kerja di perusahaan tersebut.

\subsection{Teknik Pengumpulan Data}

Pengumpulan data dilakukan melalui wawancara yang mendalam pada setiap subyek. Proses wawancara dilakukan dengan interaksi tatap muk,a antara peneliti dengan responden, dengan teknik wawancara mendalam. Di sini nara sumber, adalah instrumen utama penelitian. Selain itu, peneliti juga mengumpulkan data melalui observasi dan studi pustaka.

\subsection{Teknik Keabsahan Data}

Teknik keabsahan data yang peneliti gunakan, dalam penelitian ini adalah triangulasi metode. Menurut Pujileksono triangulasi metode dilakukan dengan cara membandingkan informasi atau data dengan cara atau metode yang berbeda. Peneliti membandingkan hasil wawancara dengan hasil observasi dan hasil dari studi pustaka yang dilakukan oleh peneliti.

\subsection{Teknik Analisis Data}

Dalam pendekatan kualitatifkonstruktivis dikenal istilah pengujian keakuratan dari subyek penelitian, yaitu kebenaran dan kejujuran dari subyek penelitian. Penelitian ini juga menggunakan prinsip itu. Dalam menganalisis data, 
peneliti akan menguji kebenaran dan kejujuran para subyek penelitian. Pengujian dalam keakuratandiuji melalui beberapa pengujian. Pertama adalah menguji kredibilitas subyek penelitian dengan menguji jawaban-jawaban pertanyaan terkait dengan pengalaman dan pengetahuan mereka yang khas.

Kedua, menguji outentik, yaitu peneliti memberikan kesempatan dan memfasilitasi pengungkapan konstruksi personal yang lebih detail. Selanjutnya, peneliti melakukan analisis triangulasi, dimana peneliti menganalisis jawaban subyek penelitian dengan meneliti autentisiitasnya berdasar data empiris yang ada. Tahapan berikutnya, peneliti melakukan analisa subjektif dimana pandangan, pendapat, ataupun data dari subyek penelitian di dialogkan dengan pendapat, pandangan ataupun data dari subyek lainnya

Hasil dari wawancara di lapangan kemudian dianalisis dan diinterpretasikan dengan menggunakan kategori-kategori analisis. Analisis data merupakan proses berkelanjutan yang membutuhkan evaluasi terus menerus dan telaah mendalam terhadap data. Mengajukan pertanyaanpertanyaan analitis yang terbuka.

\section{PEMBAHASAN}

Berikut akan disajikan hasil dan pembahasan terkait penelitian deskritif yang telah dilakukan.

\subsection{Gambaran Umum Subjek Penelitian.}

Subjek penelitian yang dipakai sebagai nara sumber adalah Bapak A, berusia 40 tahun. Guru SMA P. Pengalaman mengajar selama hampir 10 tahun. Tinggal di Jakarta, menikah dan memiliki satu putera. Bidang studi yang diempu, Bimbingan Konseling.

Bapak L, 34 tahun. Karyawan di PT. E, pada Perusahaan Swasta. Daerah Merunda- Jakarta Utara. Status masih lajang. Tinggal di jalan sawo. Jakarta timur. Terakhir, Ibu F, berusia 33 tahun, karyawati Bank UOB. Bekerja sebagai Head Legal pada Bank Swasta. Tinggal di jalan pendidikan II, Jakarta. Pengalaman bekerja 6 tahun. Menikah dan memiliki satu anak.

\subsection{Eudaimonisme Aristoteles.}

Etika Eudamonisme Aristoteles, berpangkal pada interaksi manusia dalam melakukan kegiatannya. Sebuah kajian etika yang berupaya mengukur benar atau salahnya tindakan manusia dari perbuatan yang dilakukannya. Setiap perbuatan yang dilakukan oleh manusia selalu memiliki maksud dan tujuan tertentu, yakni pada tujuan yang baik. Tujuan yang baik adalah apa yang secara kodrati menjadi arah tujuan akhir dari manusia. Didalam perbuatan yang dilakukan tersebut terkandung nilai- nilai yang mengikutinya. Dalam pemaparan lebih mendalam, Aristoteles, menguraikan bahwa yang baik, yang menjadi tujuan akhir manusia adalah kebahagiaan atau kesejahteraan (eudaimonia).

Aristoteles sadar dan paham sungguh, ada banyak pemahaman yang ditelaah untuk mengupas kebahagiaan itu sendiri. Ada yang memandang sebagai kekayaan, kemegahan, kenikmatan nafsu, memiliki kekuasaan dan kekuatan. Tapi lebih dari pada itu semua, yakni apa yang menjadi tujuan dari manusia itu sendiri.

Etika Aristoteles, merupakan etika pengembangan diri karena kebahagiaan yang menjadi orientasi manusia. Hal ini akna terlaksana, bila sejatinya manusia mengoptimalisasikan apa yang dimilikinya tersebut.

\subsection{Kepribadian Moral Konsumen Teknologi \\ Konsumen yang memiliki} kepribadian moral, adalah konsumen yang terus menerus mengupayakan dirinya, agar dapat terus menjadikan pribadi yang berguna.

Bapak A menyebutkan, "Menjadi pemakai teknologi yang benar, harus memiliki kepribadian moral yang baik. Istilah yang langsung, yakni menjadi konsumen harus sungguh- sungguh menerapkan serta melaksanakan apa yang menjadi tanggung jawab kita sebagai pemanfaat teknologi".

Ibu F menyatakan bahwa "Penting untuk secara sadar dan mendalam serta Menanamkan dalam diri sendiri suatu tekad untuk secara berani memakai teknologi pada pemakaian sebagaimana mestinya". 
Menjadi konsumen yang memakai teknologi dengan tidak memperhatikan aspek- aspek lain menjadi penilaian tersendiri.

Bapak L menyebutkan, "Bagi gue, moral yang baik penting. Teknologi baik tapi moral makin rusak ya sama aja. Seharusnya semakin baik teknologi maka moral semakin baik juga. Jangan sebaliknya, masa teknologi semakin maju, moral semakin bejad".

\subsection{Kepribadian Moral Sebagai Landasan dalam Aplikasi Teknologi}

Etika sebagai kajian tentang perilaku moral memegang peran yang penting dalam penerapan lingkup aktivitas. Penanaman karakter, yang mengarahkan perubahan sikap dan perilaku moral, harus dimulai dari para konsumen. Dalam hal ini para konsumen pemanfaat sekaligus penikmat teknologi.

Ibu F berpendapat, "Untuk menjadi konsumen yang sungguh sungguh bisa memaknai teknologi, dasarnya adalah kejujuran".

Bapak A menyatakan, "pondasi utama membangun manusia berkrakter adalah nilai kejujuran".(Bapak A)

Bapak L memiliki pandangan serupa namun dengan kondisi, "Jujur, penting sih..tapi harus liat situasi”.

Argumentasi nara sumber tersebut, seirama dan senada dengan apa yang di tuangkan dalam buku mengenai filsafat moral. Frans Magnis dalam bukunya Etika, mengatakan bahwa untuk menjadi pribadi yang kuat secara moral, harus memiiki nilai- nilai dalam hidupnya. Nilai nilai tersebut diantaranya:

1). Kejujuran

Pondasi awal untuk menjadi orang yang kuat secara moral dan utama dalam bertingkah laku adalah nilai kejujuran.

Kejujuran dipahami sebagai:

- Terbuka. Terbuka dalam hal ini tidak dipahami bahwa orang lain berhak tahu akan segala perasaan dan pikiran kita. Dalam pemahaman ini, kita harus muncul dan tampil sebagai diri kita sendiri. Berani menjadi diri sendri. Kita idak menyembunyikan wajah kita. Kita berani menunjukan wajah kita sesuai dengan keyakinan kita.

- Wajar atau fair. Kita memperlakukan orang lain sama ketika kita memperlakukan diri sendiri. Menghormati hak orang lain. Iaakan selalu memenuhi janji yang diberikan.

2). Otentik

Otentik berarti aseli, tidak tiruan. Manusia yang otentik adalah manusia yang menghayati dan menunjukan diri sesuai dengan keasliannya. Manusia yang tidak otentik adalah manusia yang dicetak dari luar. Dalam segala- galanya menyesuaikan diri., dengan kata lain selalu begantung pada keadaan sekitar. Kesediaan untuk bergatung pada lingkungan setempat.

3). Kesediaan untuk bertanggung jawab

Bertanggung jawab berarti suatu sikap terhadap tugas yang membebani kita. Kita merasa terikat untuk menyelesaikannya demi tugas itu sendiri.

4). Kemandirian Moral

Keberanian moral yang dimiliki oleh manusia, diasumsikan bahwa kita tidak pernah ikut- ikutan dengan pelbagai pandangan moral dalam lingkungan kita

\subsection{Pengolahan Kepribadian Moral}

Ada beberapa hal, yang bisa dijadikan acuan dalam pengelolaan kepribadian moral, pada para pekerja di perusahaan. Pribadi yang terus berupaya merealisasikan nilai- nilai moral tersebut dalam kehidupan sehari- hari. Pada taraf ini, dapat dikatakan, ini yang mau digaris bawahi oleh para pekerja dalam upaya mengembangkan serta memaksimalkan hasil dalam bekerja, maka mereka harus tetap dan selalu memperjuangkan nilai- nilai moral tersebut.

Ibu F menyatakan, "Bila saya dirumah, saya menjadi istri yang taat sama suami. Mendidik anak- anak dengan baik. Melayani suami dengan baik..intinya menjadi istri yang bisa membangun rumah tangga dengan baik. Menanamkan serta memberikan contoh nilai- nilai moral kepada keluarga". 
Dialog tersebut secara lugas menuturkan, kondisi pentingnya, untuk selalu mengedepankan nilai- nilai moral.. Tanpa memakai tedeng dan topeng. Pribadi selalu berusaha mewujudkan nilai- nilai moral yg di ajarkan oleh Aristoteles.

\subsection{Sikap Kepribadian Moral di Dalam Pemanfaatan Teknologi}

Dalam perspektif Aristoteles, person atau diri merupakan bentuk dari pengolahan yang dilakukan ketika berinteraksi dengan individu lainnya. Artinya dalam cakupan yang lebih luas, dapat dikatakan bahwa pelaku moral adalah pelaku yang bukan memainkan situasi yang statis. Diri dalam hal ini tidak menjadi satu peran saja. Diri mengalami perubahan dimana pada tiap- tiap interaksi mengalami dan menyesuaikan dengan keadaan.

Kegiatan yang dilakukan oleh masing- masing individu. Dalam hal ini baik karyawan, tenaga pengajar. berperan aktif dalam proses interaksi dalam kegiatannya setiap hari. Ada nilai- nilai yang dibawa ketika berinteraksi dengan sesama dalam melakukan pekerjaan. Diri sebagai wujud penejawantahan proses interaksi adalah sebuah kesadaran dimana individu sedang melakukan hubungan sosial, baik dengan sesama individu, maupun dengan kelompok lainya dalam skala yang lebih luas.

Ketika manusia sadar melakukan interaksi, maka segala macam isyarat, tanda yang dimainkan merupakan suatu bentuk buatan yang sudah dipikirkan oleh individu tersebut

Bapak A, " Saya bila berada diruangan, pakai handphone sehematnya ".

Bapak L menyebutkan, "gue, biasanya unduh berita dan main game dan berusaha habisin paket, ngandelin wifi juga dikantor".

Ibu $\mathrm{F}$ menyatakan, "saya pakai seperlunya saja. Paling pas jam istirahat baru lihat- lihat status di hand phone".

Sikap dan pernyataan yang dilakukan oleh nara sumber tersebut dibentuk oleh yang bersangkutan agar dapat tampil maksimal dalam pengaplikasiannya terhadap teknologi. Proses pengembangan diri dilakukan didalam suatu ruang gerak dengan melakukan serangkaian interaksi terhadap apa yang di hadapinya.Melalui kepribadian moral yang dilakukan dengan baik oleh para konsumen, dapat selalu menyadarkan kita tentang harkat, peranan, dan tangung jawab sebagai manusia.

\section{KESIMPULAN}

Sikap moral individu- individu konsumen melalui tindakan yang dilakukan dengan memakai teknologi, bersadar pada nilai- nilai kejujuran, keadilan, kerja keras, kedisiplinan dan sebagainya. Secara sederhana menggaris bawahi kepada kita bahwa hidup manusia yang bermoral diupayakan dan diperjuangkan sungguhsungguh.

Manusia selalu mengalami perubahan. Dan ketika setiap individu melakukan sesuatu untuk melengkapi kebutuhannya, ia melakukannya atas dasar kebutuhan yang harus dipenuhi pada dirinya. Dan kebutuhan itu hanya akan terealisasi bila kita berupaya dengan sekuat tenaga memaksimalkan potensi yang kita miliki. Kita melakukan semua hal yang kita hadapi dengan totalitas.

Melalui sikap perilaku yang kita lakukan sehari- hari, dengan mengedepankan nilai- nilai yang dikemukakan oleh Aristoteles, secara sederhana memperlihatkan kepada kita, bahwa pengimplementasian kepribadian moral, terjadi dengan baik, dan perilaku dapat terealisasi dalam dunia kerja bila karyawan menerapkan dengan baik nilainilai tersebut. Artinya nilai- nilai tersebut, sungguh sungguh dihayati dengan tindakan nyata.

didalam melakukan aktivitas kerja dilakukan dengan orientasi yang sesuai dengan prosedur. Memiliki maksud dan tujuan tertentu. Pengolahan kepribadian moral yang baik, akan menghasilkan dampak sebagai konsumen yang baik. Demikian juga sebaliknya pengolahan kepribadian moral yang tidak baik akan menciptakan para konsumen penikmat teknologi tidak baik. Kita sebagai konsumen, dalam hal ini memegang peranan yang vital. 


\section{DAFTAR PUSTAKA}

Bertens, K. (2003). Keprihatinan Moral. Yogyakarta: Kanisius.

Creswell, John W. (2010).Research Design: Pendekatan Kualitatif, Kuantitatif dan Mixed. Yogyakarta: Pustaka Pelajar.

Departemen Pendidikan Nasional. (2008). Kamus Besar Bahasa Indonesia. Jakarta: Pusat bahasa

Hadiwijono, Harun.(2015). Sari Sejarah Filsafat Barat 2. Yogyakarta: Kaisius

Leahy, Louis. (2006). Siapakah ManusiaSintesis Filosofis Tentang Manusia (pustaka filsafat) . Yogyakarta: Kanisius

Mulyana, Deddy. (2013). Metodologi Penelitian Kualitatif. Bandung: Remaja Rosdakarya.

Mangunhardjana. (2008). Isme- Isme dalam Etika. Dari A-Z. Yogyakarta: Kanisius

Suseno, Franz Magnis. (2006). Etika Abad Kedua puluh. Yogyakarta: Kanisius.

Sudarminta, J. (2013). Etika Umum- Kajian Tentang Beberapa Masalah Pokok dan Teori Normatif. Yogyakarta:Kanisius

Setyawan, S. (2013). Guru Panutanku. Yogyakarta: Kanisius

Tjahjadi, S. P. (2008). Petualangan Intelektual- Konfrontasi Dengan para Filsuf dari Zaman Yunani hingga Abad Modern. Yogyakarta: Kanisius. 